\title{
Penerapan teknologi pemanenan air hujan menuju desa mandiri air bersih di Pulau Merbau
}

\author{
Joleha ${ }^{\circledR}$, Bambang Sujatmoko ${ }^{\circledR}$, Sri Djuniati, Haji Gussafri, Bochari, Andy Hendri, dan Suprasman \\ Fakultas Teknik, Universitas Riau \\ *joleha@lecturer.unri.ac.id
}

\begin{abstract}
Abstrak. Salah satu upaya untuk mengatasi krisis air bersih di wilayah kepulauan, salah satunya Pulau Merbau adalah dengan membuat teknologi sederhana untuk menampung kelebihan air selama musim penghujan yang selanjutnya dimanfaatkan untuk berbagai keperluan tatkala air tersebut dibutuhkan. Teknologi tersebut adalah bangunan Penampung Air Hujan (PAH). Kegiatan pengabdian kepada masyarakat dilakukan dengan cara membuat percontohan bangunan PAH di salah satu rumah warga dan melakukan penyuluhan terhadap warga sehubungan dengan perhitungan dan perencanan pembangunan penampungan air hujan serta pentingnya mengkonsumsi air bersih. Tujuan dari pengabdian ini adalah memberikan pemahaman, peningkatan pengetahuan tentang perlunya teknologi pemanenan air hujan untuk memenuhi kebutuhan air bersih sehari-hari dengan infrastruktur dasar sistem penampungan air hujan yang ideal berbasis masyarakat mandiri. Volume tampungan air hujan ini dibutuhkan sebesar $3 \mathrm{~m}^{3}$ (3.000 liter) dari luas atap rumah sebesar $36 \mathrm{~m}^{2}$. Air hujan ini digunakan untuk memenuhi kebutuhan minum, masak dan cuci sebesar 15 liter/org/hr. Jumlah penghuni di dalam rumah tersebut sebesar 5 orang. Hasil yang diperoleh dari kegiatan ini adalah terbangunnya penampungan air hujan dengan volume sebesar 1.000 liter dengan perlengkapan sistem pemanenan air hujan yang baik dan benar. Dengan demikian kekurangan volume penampungan air hujan sebesar 2.000 liter lagi harus diusahakan secara mandiri oleh sipemilik rumah.
\end{abstract}

Kata kunci: krisis air bersih; penyuluhan; pemanenan air hujan; penerapan; volume tampungan

\begin{abstract}
One of the efforts to overcome the clean water crisis in the archipelago, one of them is Merbau Island, is to make a simple technology that is used to accommodate excess water during the rainy season and next, the water can be utilized for various purposes when it has been needed. The technology is rainwater storage building (PAH). This community service activity was conducted by making a model of PAH building at one of the residents' houses and conducting a counselling activity to residents in relation to both of calculation and planning of the PAH building, and also the importance of consuming clean water. The purposes of this community service are to give an understanding and increasing knowledge about the needed for rainwater harvesting technology so that daily clean water needs will be fulfilled by basic infrastructure of the ideal PAH system based on independent-communities. The volume of this rainwater reservoir is needed at $3 \mathrm{~m} 3$ (3,000 litres) from the roof area of $36 \mathrm{~m} 2$. This rainwater is used to meet the needs of drinking, cooking and washing of 15 litres/person/day. The number of residents in the house is 5 people. The results obtained from this activity are the construction of rainwater reservoirs with a volume of 1,000 litres with good and correct rainwater harvesting system equipment. Thus the lack of 2,000 litres of rainwater storage must be managed independently by the homeowner.
\end{abstract}

Keywords: clean water crisis; conseling; rainwater harvesting; volume of rainwater storage; application

To cite this article: Joleha, B. Sujatmoko, S. Djuniati, H. Gussafri, Bochari, A. Hendri, \& Suprasman. 2019.

Penerapan teknologi pemanenan air hujan menuju desa mandiri air bersih di Pulau Merbau. Unri Conference

Series: Community Engagement 1: 317-324 https://doi.org/10.31258/unricsce.1.317-324

(C) 2019 Authors

Peer-review under responsibility of the organizing committee of Seminar Nasional Pemberdayaan Masyarakat 2019 


\section{PENDAHULUAN}

Keterbatasan sumber air bersih merupakan permasalahan utama pulau-pulau di Indonesia, begitu juga di Kecamatan Pulau Merbau Kabupaten Kepulauan Meranti. Kualitas air tanah di daerah wilayah pesisir bersifat asam atau payau dengan salinitas tinggi, sehingga sebagian besar penduduk pulau tersebut memanfaatkan air hujan untuk memenuhi kebutuhan air sehari-hari (Joleha, 2017).

Salah satu upaya untuk mengatasi krisis air adalah dengan membuat teknologi sederhana untuk menampung kelebihan air selama musim penghujan dan selanjutnya dimanfaatkan untuk berbagai keperluan ketika air tersebut dibutuhkan. Teknologi tersebut adalah bangunan Penampung Air Hujan (PAH). Bangunan PAH dibuat dan berfungsi sebagai penyedia air baku domestik dengan memanfaatkan sumber air hujan yang memanfaatkan atap sebagai tempat tangkapan hujan (Hermawan, 2014). Pulau-pulau kecil memiliki daerah tangkapan air yang sangat terbatas sehingga ketersediaan air tawar merupakan hal yang memperhatinkan. Selain itu, kondisi masyarakat pulau-pulau kecil banyak yang masih hidup kekurangan, sehingga berpengaruh terhadap daya beli air bersih.

Kecamatan Pulau Merbau adalah salah satu pulau yang berada di Kabupaten Kepulauan Meranti. Selain merupakan salah satu pulau yang dikategorikan pulau kecil yang memiliki permasalahan utama dalam penyediaan air bersih, pulau ini juga terletak di luar kota kabupaten Kepulauan Meranti sehingga belum tersentuh oleh fasilitas pasokan air dari PDAM. Oleh karena hal tersebut, pemanfaatan air hujan merupakan pilihan masyarakat pulau Merbau untuk memenuhi kebutuhan air sehari-hari. Pemanenan air hujan ini sudah sejak lama dilakukan secara konvensional untuk memenuhi kebutuhan air bersih terutama sebagai air minum dan cuci.

Air hujan pada dasarnya ialah air murni atau $\mathrm{H}_{2} \mathrm{O}$ tanpa tambahan mineral, garam, dan lainnya. Namun akan terkontaminasi ketika tercampur dengan zat-zat di udara dan material yang menampungnya. Sehingga perlu pengolahan terlebih dahulu sebelum dijadikan sumber air minum. Dengan demikian kenyataan yang menggambarkan keterbatasan sumber daya air di pulau-pulau kecil, dapat diatasi dengan mengandalkan air hujan sebagai pelaksanaan sistem pengelolaan sumber daya air berkelanjutan untuk kebutuhan air bersih.

Pada umumnya sumber air baku di suatu wilayah berasal dari air permukaan, air tanah dan air hujan. Di pulau Merbau, sumber air berasal dari air hujan, air tanah dangkal dan air permukaan yang terdiri dari air sungai, air tasik dan air laut. Dari beberapa sumber air baku di atas yang dapat dijadikan sumber air bersih adalah air hujan dan air tasik, sedangkan air sumur dangkal dan air sungai adalah air payau dan air laut adalah air asin yang perlu pengolahan terlebih dahulu sebelum dijadikan air bersih. Air tasik yang dapat dijadikan air bersih juga tidak dapat langsung digunakan oleh masyarakat karena lokasi yang sangat jauh dari lokasi pemukiman, dimana perlu fasiltas insfrastuktur yang modern untuk sampai ke lokasi penduduk, sehingga satusatunya air bersih yang dapat langsung digunakan masyarakat adalah air hujan.

Desa Semukut merupakan salah satu dari 11 (sebelas) desa yang ada di kecamatan Pulau Merbau. Desa ini dipilih sebagai lokasi pengabdian, karena desa ini merupakan ibukota kecamatan dan mudah diakses setelah penyeberangan. Desa Semukut memiliki luas wilayah 4.500 Ha, merupakan wilayah yang agraris dengan mata pencaharian pokok petani karet. Desa Semukut dapat ditempuh dengan transportasi darat dan laut, dengan jarak dari kabupaten 12,7 Km dan jarak dari Provinsi $140 \mathrm{Km}$. Secara Geografis desa Semukut terletak di daerah pesisir Selat Air Hitam yang berbatasan dengan: Sebelah Utara berbatasan dengan Desa Centai atau Desa Batang Meranti; Sebelah Selatan berbatasan dengan Selat Rengit; Sebelah Barat berbatasan dengan Desa Padang Kamal, dan Sebelah Timur berbatasan dengan Selat Air Hitam. Jumlah penduduk yang ada di desa Semukut sebanyak 2.303 jiwa dengan 563 kepala keluarga. Jumlah penduduk laki-laki yang ada di desa Semukut berdasarkan data monografi desa sebanyak 1.188 jiwa dan perempuan sebanyak 1.115 jiwa. Desa Semukut terdiri dari tiga dusun yakni dusun Parit Mesjid, dusun Parit Baru dan dusun Mempalai (Profil Pulau Merbau, 2015).

Sebagaimana biasa wilayah kepulauan yang memiliki tingkat kerentanan yang sangat tinggi baik dari pembangunan ekonomi maupun pengembangan sumber daya yang dimiliki. Ukuran yang sangat kecil dengan kondisi geografi yang terisolir menimbulkan terjadinya kerentanan ekonomi yang akan memberikan dampak langsung terhadap pelaksanaan pembangunan (Briguglio, 2004). Ukuran yang kecil juga mengakibatkan dampak bencana pada perekonomian pulau akan relalif lebih besar dalam hal kerusakan per satuan luas dan biaya per kapita (Adrianto, 2002). Namun selain kekurangan yang dimiliki tersebut pulau kecil memiliki karakteristik serta kekayaan yang cukup potensial terutama untuk perikanan dan kelautan. Begitu juga didesa Semukut yang terletak di Pulau Merbau potensi lain yang dimiliki desa ini adalah masih terdapat banyak lahan 
belum terbangun/dipotensikan secara maksimal, hasil perikanan yang belum dikembangkan dan potensi hutan mangrove untuk berkembangnya ikan dan udang.

Oleh karena permasalahan di atas, maka dibutuhkan pihak yang memiliki kemampuan analitis dan teknis di bidang ekonomi, sosial, politik, budaya dan teknik dalam proses teransfer ilmu dalam penerapan di lapangan. Akademisi yang memiliki kemampuan analitis dan teknis yang memadai, dapat memberikan jasanya dengan mentransfer pengetahuan yang dimilikinya lewat serangkaian penyuluhan/pelatihan dan atau pendampingan. Melihat dan mencermati kondisi seperti ini, maka sebagai akademisi dipandang perlu untuk mengambil andil dalam pendampingan desa serta berpartisipasi dalam melakukan kegiatan pengabdian kepada masyarakat berupa Penerapan Transfer Teknologi Pemanenan Air Hujan Menuju Desa Mandiri Air Bersih Di Pulau Merbau Kabupaten Kepulauan Meranti Provinsi Riau.

Secara umum permasalahan yang mendasar di wilayah kepulauan adalah ketersediaan air bersih. Permasalahan ini sangat berdampak kepada kerentanan pengembangan pembangunan. Sumber alam yang potensial akan terhambat perkembangannya dengan ketersediaan air bersih yang tebatas. Oleh karena itu, pembangunan di Pulau Merbau khususya mengutamakan penyediaan air bersih yang cukup untuk kebutuhan hidup sehari-hari. Diharapkan dengan transfer teknologi pemanenan air hujan dapat mendukung desa mandiri air bersih di desa Semukut Kecamatan Pulau Merbau.

Pengembangan sumber daya pulau ini dapat disusun secara sistematis dengan mengutamakan pemenuhan kebutuhan air bersih. Sehingga dengan melihat potensi dan kendala yang ada, maka rumusan masalah yang akan didiskusikan pada tahun pertama melalui program desa binaan LPPM Unri adalah; Bagaimana memberikan pemahaman, peningkatan pengetahuan tentang perlunya teknologi pemanenan air hujan untuk memenuhi kebutuhan air bersih sehari-hari dengan infrastruktur dasar berbasis masyarakat mandiri di desa Semukut. Kegiatan ini bertujuan memberikan pemahaman, peningkatan pengetahuan untuk memenuhi kebutuhan air bersih sehari-hari dengan aplikasi percontohan infrastruktur dasar teknologi pemanenan air hujan berbasis masyarakat mandiri desa.

Curah hujan merupakan faktor yang penting dalam operasional system pemanenan air hujan. Wilayah dengan musim kering yang lebih panjang maupun dengan curah hujan yang tinggi membutuhkan alternatif sumber air atau tempat penampungan yang relatif besar.

Ada tiga komponen dasar yang harus ada dalam sistem pemanenan air hujan yaitu (Gambar 1):

1. Catchment, yaitu penangkap air hujan berupa permukaan atap

2. Delivery system, yaitu sistem penyaluran air hujan dari atap ke tempat penampungan melalui talang, pipa bawah, penyaringan, penampungan pertama, dan

3. Storage reservoir, yaitu tempat penyimpan air hujan berupa tong, bak atau kolam.

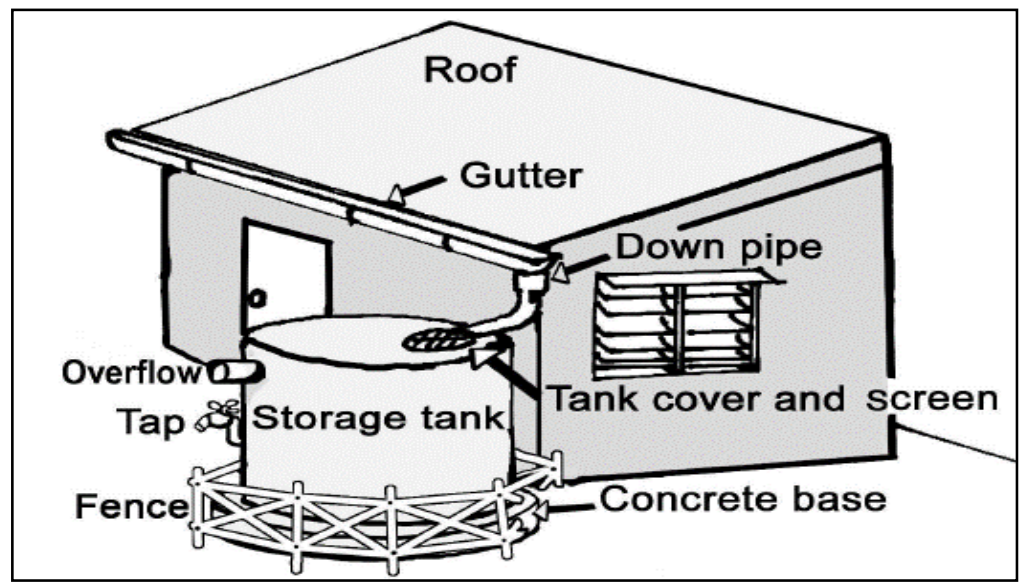

Gambar 1. Sistem pengumpulan air hujan sederhana (Timothi, 2009)

Selain ketiga komponen dasar tersebut, dapat dilengkapi dengan komponen pendukung seperti pompa air untuk memompa air dari bak atau kolam penampung (Worm \& Hattum, 2006). Kebutuhan air bersih berbeda antara satu kota dengan kota yang lainnya. Kebutuhan air bersih di desa Semukut hanya dipriorrtaskan untuk minum,masak dan membilas pakaian. Kebutuhan ini diperkirakan sekita 15 liter/jiwa/hari. Kualitas air hujan umumnya cukup baik (UNEP, 2001). Air hujan hampir tidak mengandung kontaminasi. Oleh karena itu air tersebut sangat bersih dan bebas kandungan mikroorganisme. Namun ketika air hujan tersebut kontak dengan 
permukaan tangkapan air hujan (catchment), tempat pengaliran air hujan (conveyance), dan tangki penampungan air hujan, maka air tersebut akan membawa kontaminasi baik fisik, kimia maupun mikrobiologi.

Penelitian Kahinda et al., (2007) menunjukkan kesimpulan yang berbeda mengenai kualitas air hujan dari atap rumah. Kualitas air hujan dari atap rumah sangat bergantung pada karakteristik wilayah seperti topografi, kondisi cuaca, tipe wilayah tangkapan air hujan, tingkat pencemaran udara, tipe tangki penampungan dan pengolahan air hujan.

Sementara kondisi sarana dan prasarana pemanenan air hujan yang dimiliki penduduk sifatnya konvensional. Keseluruhan sistem pemanenan air hujan tidak dilengkapi dengan komponen-komponen yang selayaknya penampungan air hujan yaitu terdiri dari area tangkapan, sistem penyaluran dan tangki penyimpanan. Kondisi ini menyebabkan hasil penampungan tidak maksimal dan memperlambat proses penampungan serta kualitas air yang kurang higienis (Gambar 2).
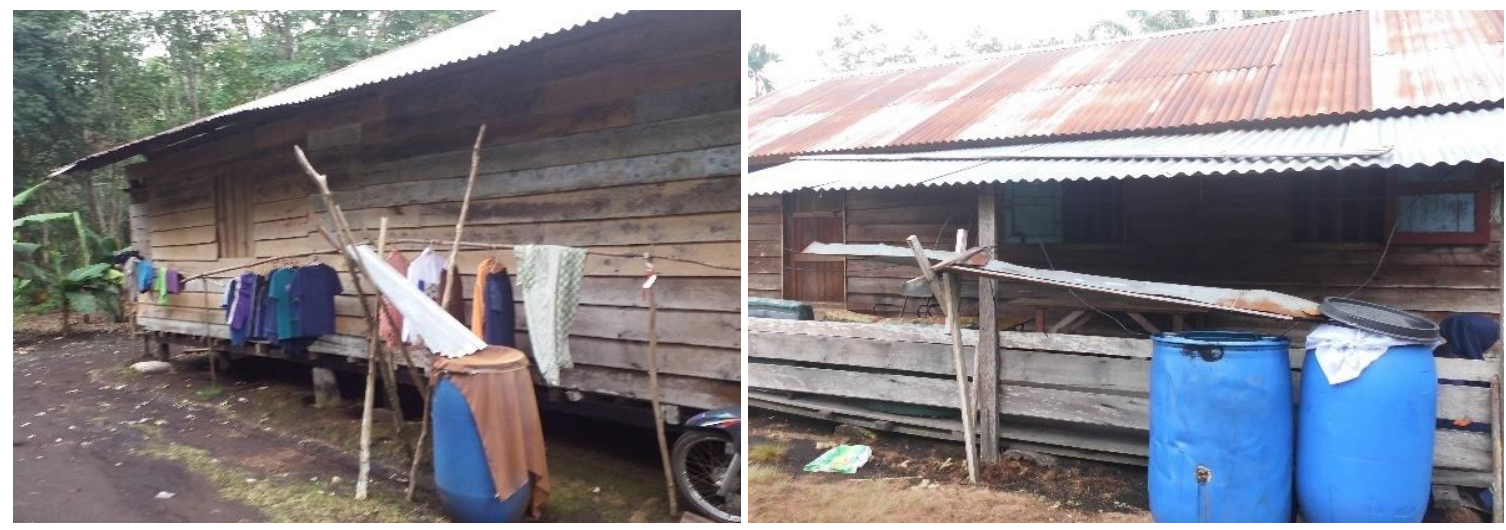

Gambar 2. Penampungan Curah Hujan di salah satu rumah penduduk Pulau Merbau (Joleha, 2017)

Sistem penyaluran air hujan biasanya dari saluran tergantung atau talang air yang terletak di sisi atap, saluran tersebut terpasang miring terhadap pipa pengumpul agar air dapat dialirkan dari atap menuju sistem penyimpanan. Untuk efektifitas operasiaonal sistem pemanenan air hujan, perencanaan sistem penyaluran yang baik dan hati-hati merupakan hal yang sangat penting karena saluran atau talang sering menjadi titik kelemahan dalam sistem pemanenan air hujan. Sebanyak 90\% atau lebih air hujan yang dikumpulkan saluran atau talang dari atap akan disalurkan menuju sistem penyimpanan apabila sistem penyaluran atau talang tersebut terpasang dengan benar dan dalam kondisi baik (Otti \& Ezenwaji, 2013).

Penerapan sistem teknologi pemanenan air hujan sangatlah penting untuk diketahui sehingga hasil pemanenan air hujan dapat diperoleh secara optimal, dan air hujan yang jatuh sebelum sampai ke tanah dapat dimanfaatkan sebagai air bersih yang merupakan sumber air baku satu-satunya di daerah kepulauan terutama di desa Semukut. Hal ini dapat mengurangi/menghemat pengeluaran pembelian air bersih.

\section{METODE PENERAPAN}

Tahapan kegiatan yang telah dilaksanakan adalah mengimplementasikan Infrastruktur dasar pemanenan air hujan skala rumah tangga secara baik dan benar sehingga diperoleh hasil penampungan yang optimal dan higienis pada tahun pertama (2018) adalah:

1. Penyampaian materi kepada warga melalui metode ceramah dan diskusi yang dilakukan di kantor Desa Semukut Pulau Merbau Kabupaten Kepulauan Maranti. Disampaikan juga tentang kuliatas air bersih menurut Permenkes No. 492/ Menkes/Per/IV/2010. Kegiatan ini bertujuan untuk memindahkan materi atau pengetahuan dari tim pelaksana kepada masyarakat desa. Sebelum materi disampaikan, hand out/modul yang berisi materi kegiatan dibagi-bagikan kepada para peserta agar mereka dapat mempelajari dan menanyakan hal-hal yang tidak dimengerti.

2. Setelah sesi penyampaian materi, dilakukan sesi tanya jawab dan diskusi untuk membahas hal-hal yang kurang dipahami warga. Kegiatan tersebut dapat dilihat pada Gambar 3. 

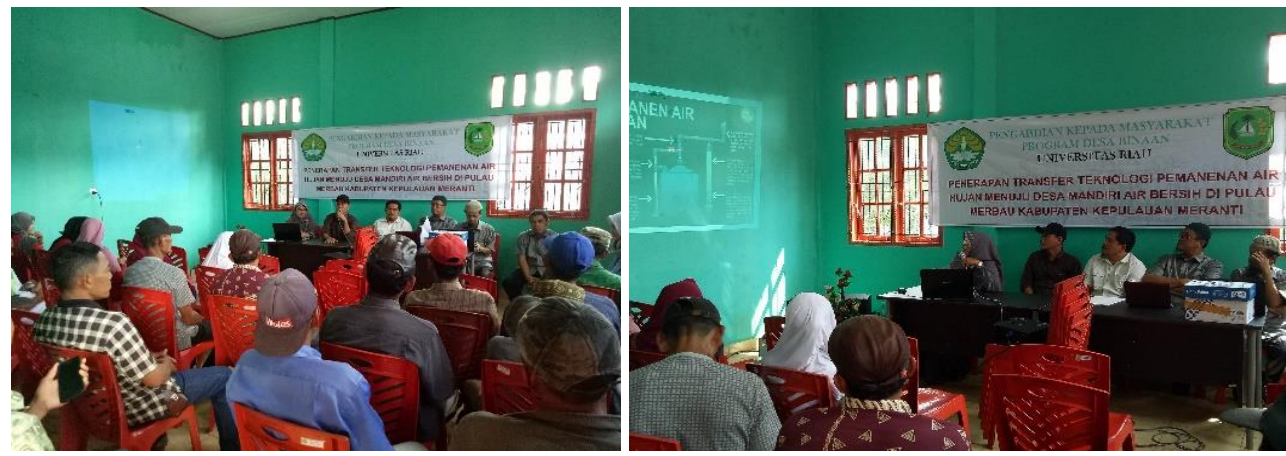

Gambar 3. Kegiatan ceramah dan diskusi transfer teknologi penampungan (pemanenan) air hujan (PAH) di Desa Semukut 2018

3. Setelah kegiatan ceramah dan diskusi selesai dilakukan, berikutnya dilakukan kegiatan pelatihan teknis yang berhubungan dengan teknis infrastruktur pemanenan air hujan skala rumah tangga.

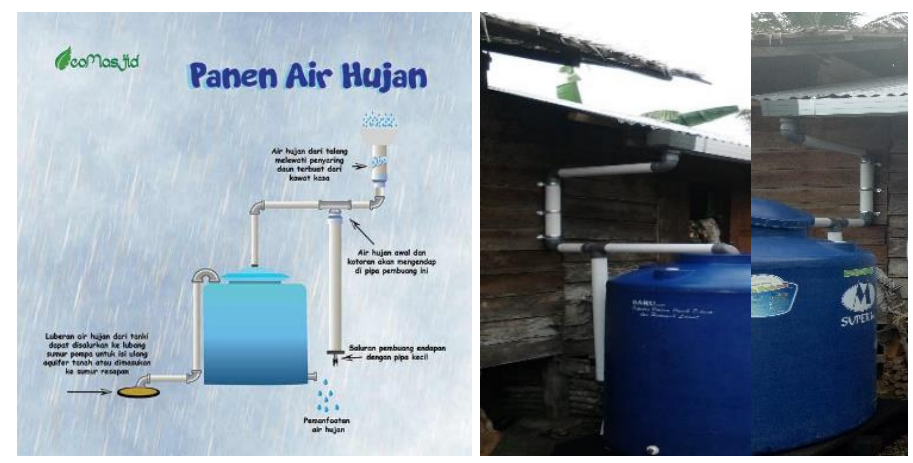

Gambar 4. Skema Pemasangan Komponen PAH (EcoMasjid dan aplikasi, 2018)

4. Aplikasi terhadap materi yang sudah dijelaskan, dilakukan pada salah satu rumah warga sebagai percontohan. Hasil pada kegiatan tersebut dapat dilihat pada Gambar 5.
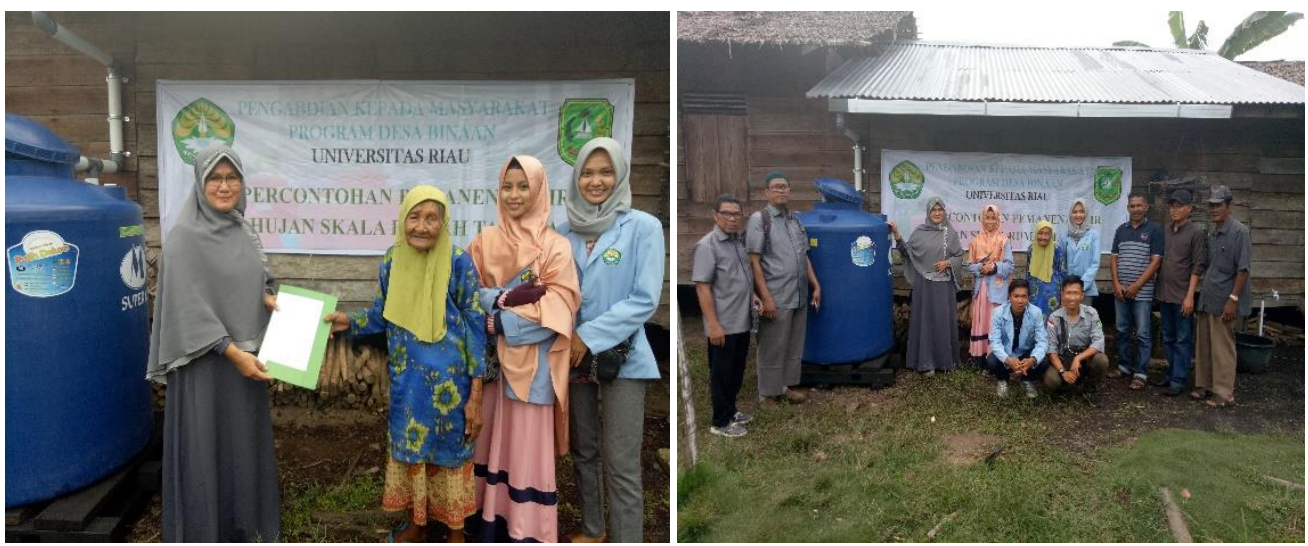

Gambar 5. Kegiatan aplikasi transfer teknologi penampungan (pemanenan) air hujan (PAH) di desa Semukut 2018

Secara rinci pokok bahasan yang telah disampaikan pada pelaksanaan ini adalah:

Pokok Bahasan 1: Pemahaman Perlunya Memanfaatkan Air Hujan

a) Pengetahuan pemenuhan kebutuhan air bersih bagi manusia

b) Kendala dan solusi pemenuhan kebutuhan air bersih

c) Pengetahuan tentang kualitas air bersih berdasarkan standar Permenkes No.492/Menkes/Per/IV/2010.

d) Pengetahuan tentang pemanfaatan air hujan sebagai air bersih

Pokok Bahasan 2: Kebutuhan Infrastruktur Dasar Pemanenan Air hujan

a) Sarana dan prasarana pemanenan air hujan 
b) Kualitas air hujan alami dan air hujan hasil tampungan

Pokok Bahasan 3: Perencanaan Sarana Prasarana Desa

a) Fasilitasi Penyusunan Rencana Teknis Pemanenan air hujan

b) Desain sistem pemanenan air hujan yang memenui standar kualitas air minum dan peawatannya.

c) Fasilitasi Penyusunan Rencana Anggaran Biaya Pemanenan air hujan

\section{Teknik Penyelesaian Masalah}

Program Pengabdian Masyarakat Desa Binaan ini khalayak sasarannya adalah Desa Semukut yang merupakan salah satu desa di Pulau Merbau. Wilayah Pulau pada umumnya mengandalkan air hujan untuk memenuhi kebutuhan air bersihnya sehari-hari. Kondisi ekonomi masyarakat di pulau ini sebagian berada pada garis bawah sehingga sebahagian besar dari jumlah rumahtangga tidak memiliki penampungan curah hujan yang memadai. Jikapun ada bak penampungan curah hujan yang disediakan, baik disediakan secara pribadi maupun bantuan pemerintah, pemasangan sistem pemipaan dari sarana penampungan curah hujan tersebut sangat tidak memadai untuk memperoleh tampungan curah hujan secara maksimum oleh sarana tersebut.

\section{Alat Ukur Ketercapaian}

Ketercapaian dari kegiatan yang dilakukan diketahui dengan melakukan tanya jawab sebelum dan sesudah penyuluhan dan pada saat aplikasi lapangan. Materi tanya jawab berhubungan dengan materi yang diberikan dalam penyuluhan.

\section{HASIL DAN KETERCAPAIAN SASARAN}

Karakteristik masyarakat Pulau Merbau yang memiliki mata pencarian beragam yakni sebagai petani karet, petani sagu, petani kelapa, nelayan, dan karyawan pemerintah, maupun swasta. Jumlah penduduk miskin hampir mendekati 50\% dari penduduk Pulau Merbau. Oleh karena itu dukungan Pemerintah Daerah sangat diperlukan dalam bentuk subsidi dana baik untuk pelaksanaan maupun pemeliharaan rutin terhadap sarana dan prasarana khususnya air bersih yang sudah atau akan dibangun. Sehingga sarana dan prasarana tersebut diharapkan terus berjalan dan berkelanjutan. Dengan demikian partisipasi masyarakat Pulau Merbau sangat penting sesuai dengan pernyataan oleh Conyers (1991), ada tiga alasan utama mengapa partisipasi masyarakat dalam program pembangunan sangat penting, pertama, partisipasi masyarakat merupakan suatu alat guna memperoleh informasi mengenai kondisi, kebutuhan dan sikap masyarakat setempat, yang tanpa kehadirannya program pembangunan akan gagal; kedua, masyarakat akan lebih mempercayai program pembangunan jika merasa dilibatkan dalam proses persiapan dan perencanaannya, karena mereka akan lebih mengetahui seluk beluk proyek tersebut dan akan mempunyai rasa memiliki terhadap proyek tersebut; ketiga, merupakan suatu hak demokrasi bila masyarakat dilibatkan dalam pembangunan masyarakat sendiri.

Masyarakat yang tinggal di Pulau Merbau mereka menyadari bahwa mereka tinggal di daerah yang sulit air, mereka menetap di lokasi tersebut karena sudah turun temurun, dekat dengan pekerjaan, dan kondisi ekonomi keluarga yang memaksa mereka hanya mampu menampung air hujan dengan wadah seadanya untuk memenuhi kebutuhan air bersihnya sehari-hari. Potensi yang dimiliki masyarakat dari segi pendanaan sangat kecil karena masyarakat yang merupakan ekonomi lemah hanya mampu memenuhi kebutuhan pokok dari penghasilan mereka sebagai petani dan nelayan. Namun untuk partisipasi dilapangan masyarakat mau aktif berpartisipasi.

Percontohan pemanenan air hujan sebagai aplikasi dari kegiatan ini sangat membantu memotivasi masyarakat bahwa melaksanakan sistem pemanenan air hujan dengan baik dapat memberi hasil tampungan air hujan secara maksimal dan higienis. Masyarakat yang terlibat dalam aplikasi lapangan mengungkapkan bahwa mereka mendapatkan pengalaman dan tahu bagaimana sistem pemipaan yang benar pada pembuatan PAH setelah turun langsung di lapangan. Gambar 6 menunjukkan perbedaan pelaksanaan pemasangan sebelum (Gambar 6.a) dan setelah pelatihan (Gambar 6.b) 


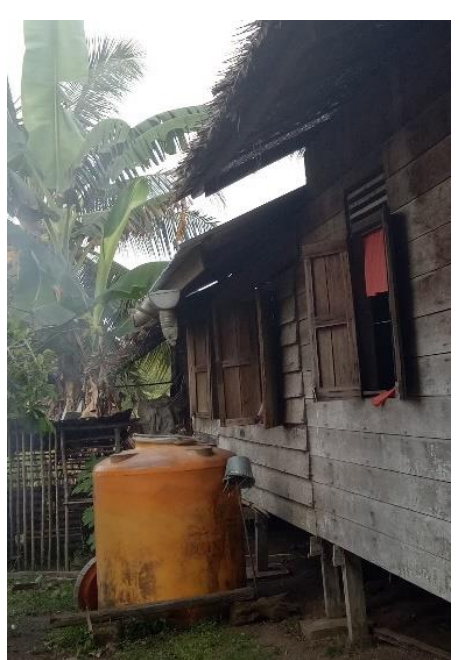

(a)

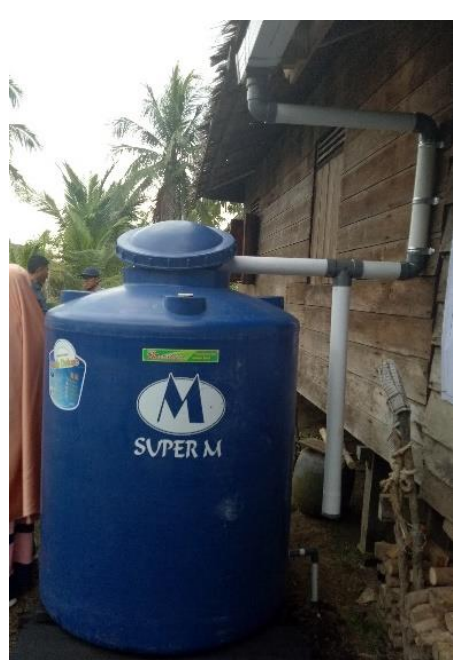

(b)

Gambar 6. Sistem Pemanenan Air Hujan

Ketercapaian dari kegiatan yang dilakukan yakni pelatihan dan sosialisasi teknik penerapan pemanenan air hujan menuju desa mandiri air bersih di Desa Semukut, dapat meningkatkan pengetahuan masyarakat tentang aplikasi dan pemenuhan air bersih secara optimal. Adapun perubahan pasca pengabdian di desa ini yang diharapkan ditunjukkan pada Tabel 1.

Tabel 1. Ketercapaian Kegiatan Pengabdian Desa Binaan

\begin{tabular}{|c|c|c|c|}
\hline No & Uraian & Pra Desa Binaan & Pasca Desa Binaan \\
\hline 1. & $\begin{array}{l}\text { Keterampilan teknis instalasi pemipaan } \\
\text { penampungan air hujan }\end{array}$ & $\begin{array}{l}\text { Tidak memiliki } \\
\text { keterampilan }\end{array}$ & $\begin{array}{l}\text { Mengerti keterampilan dan } \\
\text { akan mengaplikasikannya }\end{array}$ \\
\hline 2. & $\begin{array}{l}\text { Keterampilan menghitung kebutuhan } \\
\text { volume bak yang dibutuhkan setiap kepala } \\
\text { keluarga }\end{array}$ & $\begin{array}{l}\text { Tidak memiliki } \\
\text { keterampilan }\end{array}$ & $\begin{array}{l}\text { Mampu menghitung } \\
\text { volume bak yang } \\
\text { dibutuhkan }\end{array}$ \\
\hline 3. & $\begin{array}{l}\text { Upaya menyediakan tanki penampung } \\
\text { hujan }\end{array}$ & Tidak ada & $\begin{array}{l}\text { Ada keinginan untuk } \\
\text { mengupayakan }\end{array}$ \\
\hline 4. & $\begin{array}{l}\text { Ketrampilan mengetahui kualitas air bersih } \\
\text { berdasarkan sifat fisik kualitas air besih }\end{array}$ & Belum tahu & Jadi tahu \\
\hline 5. & $\begin{array}{l}\text { Kesadaran pentingnya mengkonsumsi air } \\
\text { bersih }\end{array}$ & Mengkonsumsi air merah & $\begin{array}{l}\text { Mengupayakan minum air } \\
\text { bersih (tidak berwarna) }\end{array}$ \\
\hline
\end{tabular}

\section{KESIMPULAN}

Adapun kesimpulan yang dapat dirangkum selama pelaksanan pengabdian ini adalah;

1. Adanya ketertarikan masyarakat untuk lebih mengetahui cara teknis pemasangan sistem pemanenan air hujan secara baik dan benar untuk dapat menghasilkan tampungan air hujan secara bersih dan optimal.

2. Masyarakat diberikan pandangan bahwa sebaiknya mengkonsumsi air bersih yang sesuai standar air bersih secara fisik tidak berwarna dan tidak berasa, namun karena kebiasaan yang telah dilakukan oleh masyarakat menggunakan air merah untuk memenuhi kekurangan air bersih sehingga perlu waktu yang lebih lama untuk merubah kebiasaan mereka meminum air berwarna tersebut.

3. Dana Aplikasi teknologi pemanenan air hujan ini hanya mampu menyumbangkan satu tanki air berkapasitas 1.000 liter. Pada kasus ini masih dibutuhkan lagi bak penampungan dengan kapasitas 2.000 liter. Jika masyarakat mampu mengeluarkan biaya untuk membuat fasilitas penampungan sesuai perhitungan kebutuhan air yang mereka butuhkan, maka atas dukungan luas atap dan curah hujan yang ada mampu memenuhi kebutuhan air bersih masyarakat pulau Merbau pada umumnya serta desa Semukut khususnya. 


\section{UCAPAN TERIMA KASIH}

Kami mengucapkan terima kasih atas dukungan dana kepada Lembaga Pengabdian Kepada Masyarakat (LPPM) UNRI tahun 2018 pada skema Desa Binaan dengan nomor kontrak 1356/UN.19.5.1.3/PP/2018 Tanggal 31 Mei 2018. Kami juga mengucapkan terima kasih kepada Kepala Desa Semukut yang dengan tangan terbuka menerima tim untuk melaksanakan kegiatan kepada masyarakat desa binaan di Desa Semukut dan tak lupa pula terimakasih kepada sebahagian mahasiswa Kukerta bimbingan ketua tim di lokasi Kecamatan Pulang Rangsang.

\section{DAFTAR PUSTAKA}

Adrianto, L. 2002. Developing economic vulnerability indices of environmental disasters in small island regions. Environmental Impact Assessment Review. Kagoshima, Japan.

Briguglio, L. 2004. Economic Vulnerability and Resilience: Concepts and Measurements. Economics Vulnerability and Resilience of Small States, Malta: Islands and Small States Institute and London: Commonwealth Secretariat.

Conyers, J. 1991. Kota Berkelanjutan (Sustainable City). Semarang: Undip.

Hermawan, K. FX. 2014. Pola Pengelolaan Penampung Air Hujan (PAH) Berbasis Modal Sosial; (Studi Kasus Di Pulau Ende Dan Pulau Solor Provinsi Nusa Tenggara Timur). Jurnal Sosek Pekerjaan Umum 6(2): 78-139.

Joleha. 2017. Model Pengelolaan Sumber Daya Air Pada Pulau Kecil Menggunakan Pendekatan Eko-Drain (Studi Kasus: Pulau Merbau Kabupaten Kepulauan Meranti). Disertasi Progres 1 Program Pascasarjana. Universitas Riau.

Kahinda, M., A. E. Taigbenu, \& J. R. Boroto. 2007. Domestic rainwater harvesting to improve water supply in rural South Africa. Physics and Chemistry of the Earth 32: 1050-1057.

Otti, V. I. \& E. E. Ezenwaji. 2013, Enhancing Community-Driven Initiative in Rainwater Harvesting in Nigeria. International Journal of Engineering and Technology 3(1).

Kecamatan Pulau Merbau. 2015. Profil Pulau Merbau. Kecamatan Pulau Merbau.

Timothy, M. M. 2009. An Analysis of Household Rainwater Harvesting Systems in Falelima Samoa. A Report for the degree of Master of Science in Civil Engineering, Michigan Technological University.

United Nations Environment Programme (UNEP) International Technology Centre. 2001. Rainwater Harvesting, Murdoch University of Western Australia.

Worm, J., \& T. van. Hattum. 2006. Rainwater Harvesting For Domestic Use, Agrodok 43, ICCO and AIDEnvironment, Agromisa Foundation and CTA, Wageningen. 